\title{
Determination of Radionuclides in Borehole Water in the Adenta Municipality of Greater Accra Region
}

\author{
H. K. Agyeman ${ }^{*}$, T. Glover2, B. J. Nyarko1,2, S. Osae1,2, E. O. Darko',2, F. Adeku1, J. K. Amoako1,2, \\ J. Owusu-Banahene',2, S. Inkoom ${ }^{1,2}$, B. K. Agyeman', M. Abubakar'1, P. O. Manteaw ${ }^{1}$, E. Amoatey ${ }^{1}$, \\ 0. Gyamfi ${ }^{2}$, D. F. Charles ${ }^{1}$
}

${ }^{1}$ Radiation Protection Institute, Ghana Atomic Energy Commission, , Legon, Accra, Ghana

${ }^{2}$ Graduate School of Nuclear and Allied Sciences, University of Ghana, Atomic Campus, Accra, Ghana

Email: *jewel5w@yahoo.com

How to cite this paper: Agyeman, H.K., Glover, T., Nyarko, B.J., Osae, S., Darko, E.O., Adeku, F., Amoako, J.K., Owusu-Banahene, J., Inkoom, S., Agyeman, B.K., Abubakar, M., Manteaw, P.O., Amoatey, E., Gyamfi, O. and Charles, D.F. (2019) Determination of Radionuclides in Borehole Water in the Adenta Municipality of Greater Accra Region. Open Access Library Journal, 6: e5560.

https://doi.org/10.4236/oalib.1105560

Received: August 9, 2019

Accepted: August 23, 2019

Published: August 26, 2019

Copyright $\odot 2019$ by author(s) and Open Access Library Inc.

This work is licensed under the Creative Commons Attribution International License (CC BY 4.0).

http://creativecommons.org/licenses/by/4.0/

\begin{abstract}
This study was carried out in the Greater Accra Region of Ghana mainly in the Adenta Municipality to determine the baseline radioactivity levels of naturally occurring radioactive material of water in boreholes using gamma spectrometry. According to WHO, the recommended limit of total committed annual effective dose should be $100 \mathrm{uSv} / \mathrm{yr}$ for radioactive materials such as ${ }^{40} \mathrm{~K},{ }^{226} \mathrm{Ra}$ and ${ }^{232} \mathrm{Th}$, which will be the subject of interest in the borehole water in the Adenta Municipality. Their average total committed annual effective dose due to intake was estimated to be $33.86 \mu \mathrm{Sv} / \mathrm{yr}$, respectively, which is far below the WHO recommended value. The average activity concentrations of ${ }^{40} \mathrm{~K},{ }^{226} \mathrm{Ra}$ and ${ }^{232} \mathrm{Th}$ in the fifth teen boreholes were measured as follows, $8.76 \mathrm{~Bq} / \mathrm{L} \pm$ to $1.28 \mathrm{~Bq} / \mathrm{L}$ for ${ }^{40} \mathrm{~K}, 0.82 \mathrm{~Bq} / \mathrm{L} \pm$ to $0.15 \mathrm{~Bq} / \mathrm{L}$ for ${ }^{226} \mathrm{Ra}$ and $0.69 \mathrm{~Bq} / \mathrm{L} \pm$ to $0.11 \mathrm{~Bq} / \mathrm{L}$ for ${ }^{232} \mathrm{Th}$ respectively. Two of the boreholes exceeded the WHO recommended values for total committed annual effective dose. These are $\mathrm{BW}_{2}$ and $\mathrm{BW}_{7}$ with recording values of 138.41 and 131.21 respectively. The results from this study will serve as baseline data for further research in the Adenta Municipality.
\end{abstract}

\section{Subject Areas}

Analytical Chemistry, Environmental Chemistry

\section{Keywords}

Boreholes, Radionuclides, Inhabitants, Exposure and Norms 


\section{Introduction}

In Ghana, the reliability of groundwater as a source of water is essential for economic development and environmental sustainability's. Recently, a number of studies have shown that boreholes have a higher level of radionuclides concentrations than hand dug wells and surface water. Water plays a vital role in the society but its scarcity is a serious global issue because of its use in the developing world [1].

The inhabitants in many societies do not get adequate water supply so they depend on groundwater for drinking, domestic and agricultural purposes and water vendor and this contributes to about one third of the total population lacking access to adequate water supply.

It is found out that hand-dug wells and dugouts are usually turbid and contain coliforms count and nitrate and there are normal uses for agricultural purposes rather than domestic purposes [2].

Borehole water is found out to be safer for drinking and it can be used as domestic purpose due to rapid population growth and urbanization has surpassed local government efforts to expand basic water services. A lot of urban African population have been limited and in some cases eliminated [3].

There is a risk involved in the exposure to radiological health hazards as shown in Table 1 and this is due to the existence of naturally occurring radionuclides in borehole water.

\section{Sources of Radionuclides in Drinking Water}

Water normally contains traces of radionuclide as shown in Figures 1-3 respectively. According to Forte et al., freshwater and ground waters normally have variety of radionuclides with the freshwater usually exposed to radioactive fallouts? The composition and concentration of radionuclides in water vary depending on the source of the water, the composition of the rock and soil structures at that location [4]. However, the current increase in radionuclide concentration in drinking water has been attributed to human activities including the wrongful disposal of radioactive material from the industrial and medical sector, technological processes involving radioactive materials such as phosphate fertilizer production, processing of mineral sands and mining, or limited control of sources including nuclear fuel cycles [5]. These processes introduce radioactive species such as uranium and thorium series into surface and underground water

Table 1. Demonstrates a decay series of uranium and thorium their half-lives and end products.

\begin{tabular}{cccc}
\hline Series & Starting Isotopes & Half-life/years & Stable End Product \\
\hline Uranium-235 & ${ }^{235} \mathrm{U}_{92}$ & $7.04 \times 10^{8}$ & ${ }^{207} \mathrm{~Pb}_{82}$ \\
Uranium-238 & ${ }^{238} \mathrm{U}_{92}$ & $4.478 \times 10^{9}$ & ${ }^{206} \mathrm{~Pb}_{82}$ \\
Thorium-232 & ${ }^{232} \mathrm{Th}_{90}$ & $1.41 \times 10^{10}$ & ${ }^{208} \mathrm{~Pb}_{82}$ \\
\hline
\end{tabular}




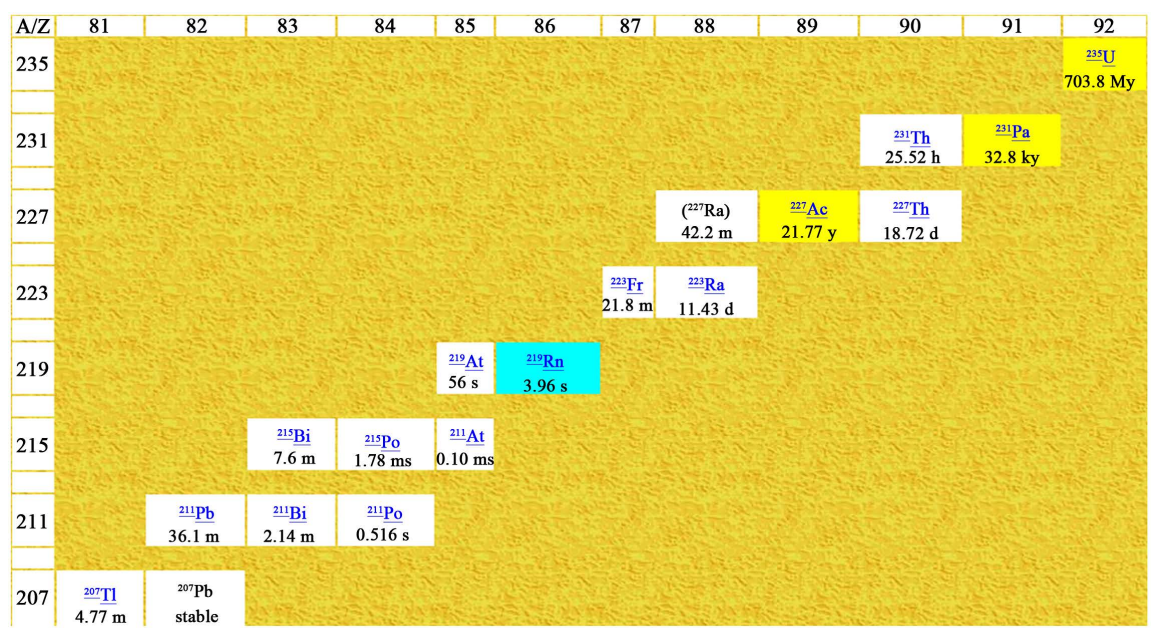

Figure 1. Shows a decay scheme of uranium-235.

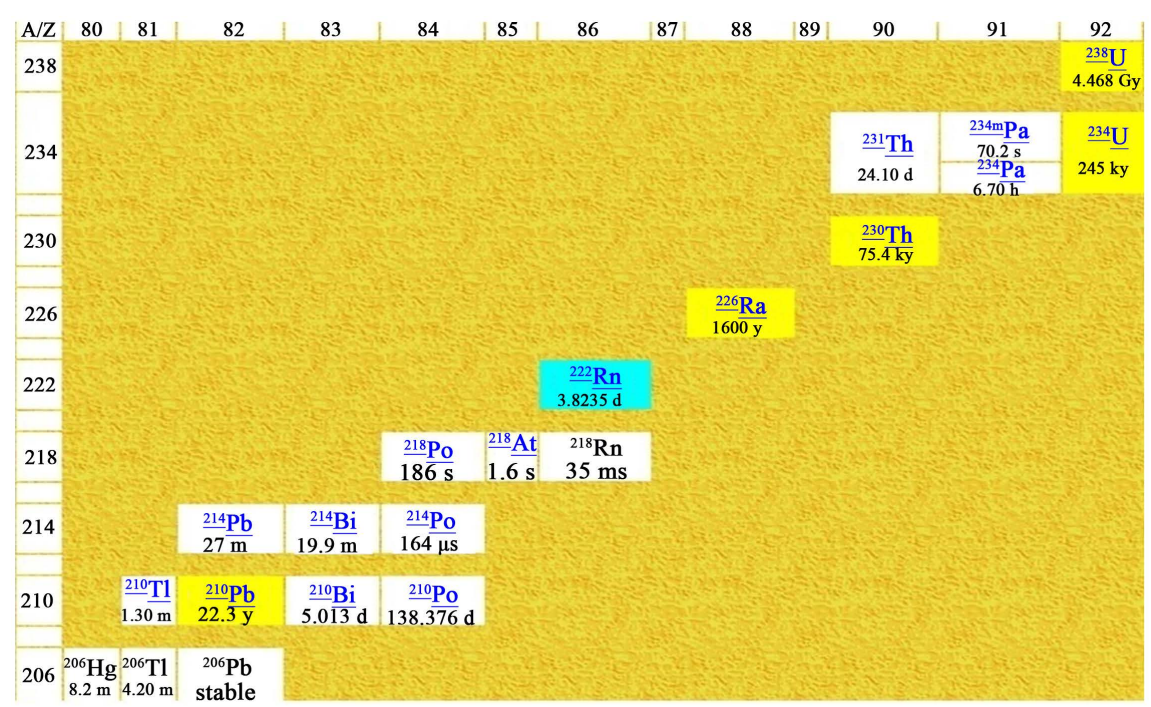

Figure 2. Shows a decay scheme of uranium-238.

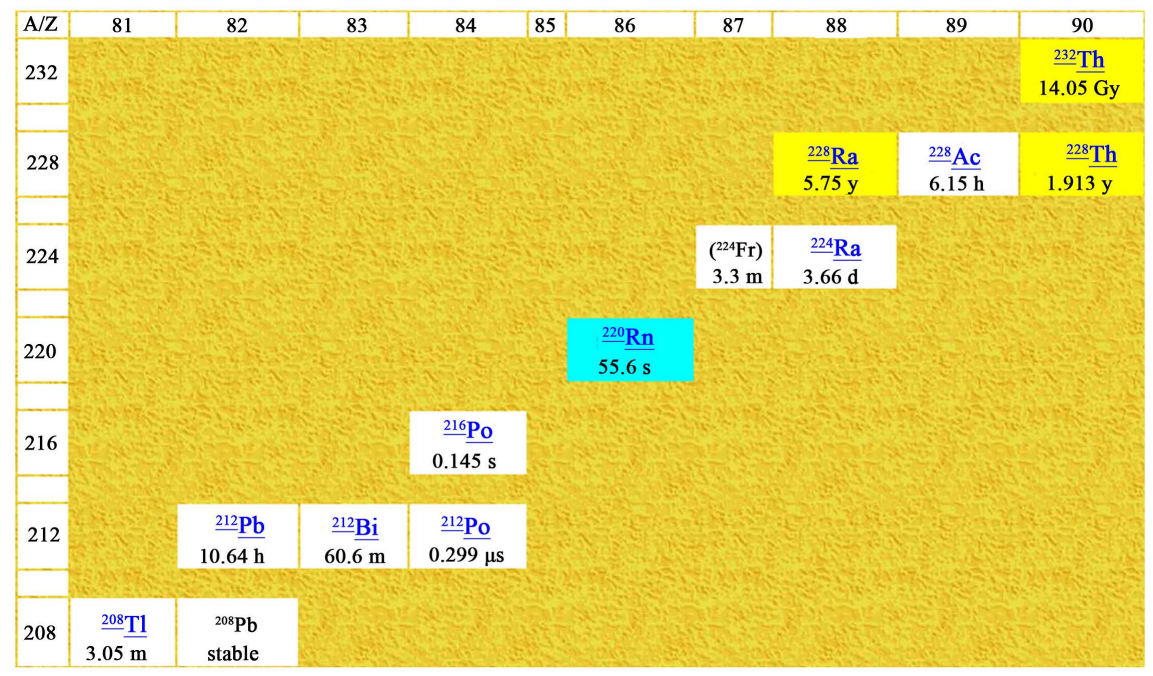

Figure 3. Shows a decay scheme of thorium-232. 
through leaching, dissolution and the recoil process. The recoil process is a physical effect which occurs when ionizing radiation is emitted, causing the mobilization of a radioactive element from its initial position. The ionizing radiation can be transferred directly to the pore space in a rock and cause a radionuclide to lose its position in the crystalline structure of the mineral and be released into underground water [6] [7]. These processes can increase the concentration of radionuclides in drinking water to levels that are harmful to humans when ingested. Therefore, there is a need to ensure that drinking water does not contain a potentially dangerous concentration of radiation.

\section{Materials and Methods}

\subsection{Study Area}

Basically the main study area was conducted in the Adenta Municipality in the Accra Metropolis of Greater Accra Region, in Ghana as shown in Figure 4. Adenta has two main rainfall patterns and it is found within the wet-semi equatorial climate region. The primary rainfall pattern begins in May to June and the secondary rainfall part hen starts from September to October. Most at times, the recorded temperature is $26^{\circ} \mathrm{C}$.

Among the sixteen districts in the Greater Accra Region, Adenta is specially one of the sixteen districts in Greater Accra Region and it is found on Latitude $5 ' 43$ " north and longitude 0'09" west and located 10 kilometres to the North-east of Accra as shown in Figure 4, Figure 5(a) and Figure 5(b) respectively.

There are several rivers in Adenta, prominent among are the Ogbojo stream and Nugete River. Water scarcity is common in the municipality. The inhabitant normally relies on water vendors, built tanks and pollutants to store water. The boreholes water samples are then transported into the Alpha spectrometry Laboratory of Ghana Atomic Energy Commission for storage, preparation and analysis.

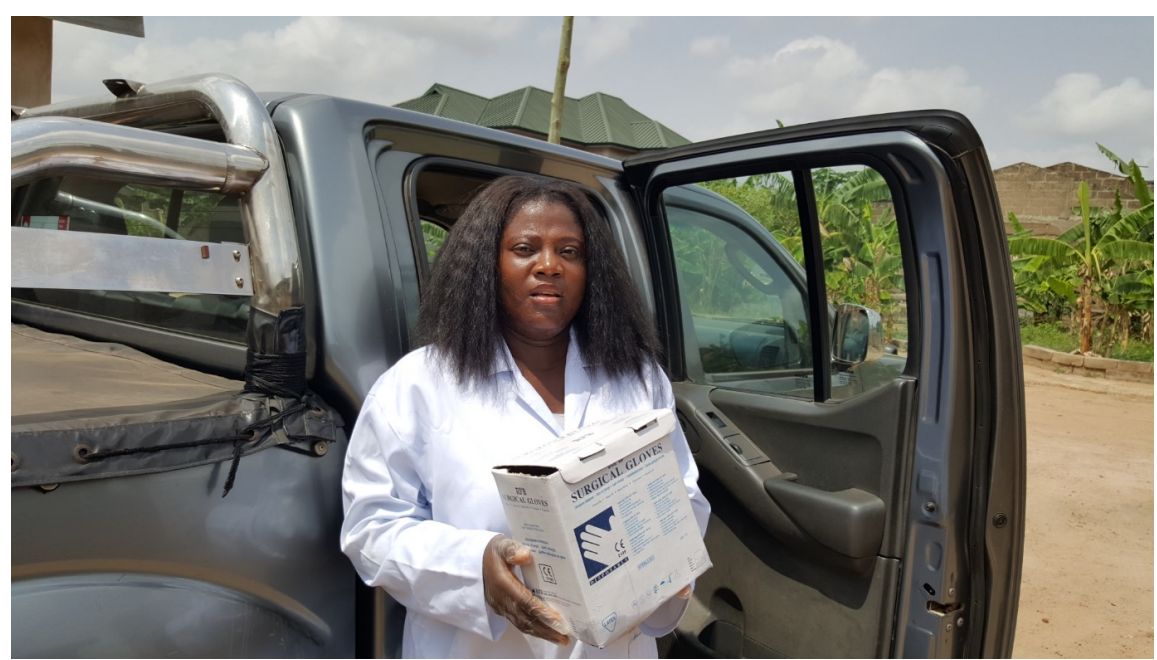

Figure 4. Shows a laboratory technologist preparing to go the field to collect borehole samples in the Adenta Municipality. 


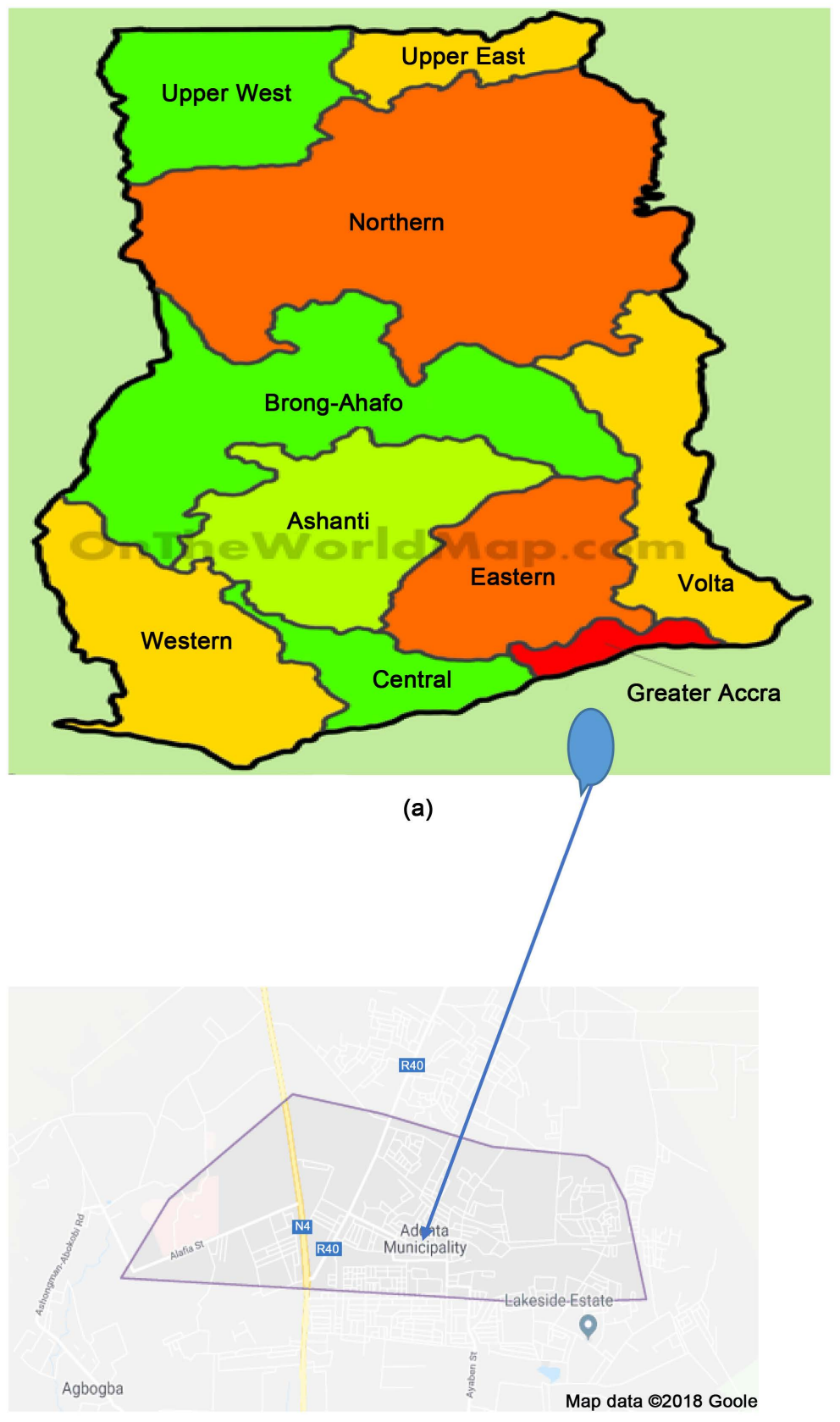

(b)

Figure 5. (a) Shows a map of Ghana with global position system (GPS) Showing Adenta municipality; (b) Shows a map showing Adenta Municipality.

\subsection{Sample Preparation for Gama Spectrometry Analysis.}

$1000 \mathrm{ml}$ of the borehole water samples were filled in a clean Marilina Beakers and tightly sealed for a period of one month to in order to permit daughter radionuclides to attain equilibrium with parent radionuclide. Daughter nuclides are the remaining nuclide left over from radioactive decay. Each borehole water sample was weighed and the masses were also recorded. Later each sample was analysed using a gamma spectrometry system with a counting assembly. 


\subsection{Instrumentation}

The electronic analyser that was used for the measurement was a Gamma-Spectrometry system, which is attached to a computer-based multichannel analyser. The Gamma Spectrometry system is also made up of n-type HPGE detector.

The energy resolution of the detector is $1.8 \mathrm{KeV}$ at gamma ray of $1332 \mathrm{KeV}$ of Co and a relative efficiency of $25 \%$. A quality control measure is conducted on the detector to determine the background distribution of the detector and is performed by filling eight (8) Marilina beakers with distilled water and counted for $36,000 \mathrm{~s}$ in the same geometry as the samples.

A software known as Genie - 2000 is used to determine the qualitative analysis of radionuclides and identifying individual's radionuclides as shown in Figure 6 respectively. This was done by using their gamma ray energies. A background spectra was used to determine the minimum detectable activities of ${ }^{40} \mathrm{~K}$ $(0.19 \mathrm{~Bq} / \mathrm{L}){ }^{226} \mathrm{Ra}(0.11 \mathrm{~Bq} / \mathrm{L})$ and ${ }^{232} \mathrm{Th}(0.13 \mathrm{~Bq} / \mathrm{L})$ respectively [8] [9]. The net peaks areas of the peaks areas of the gamma rays were collected using the background spectra.

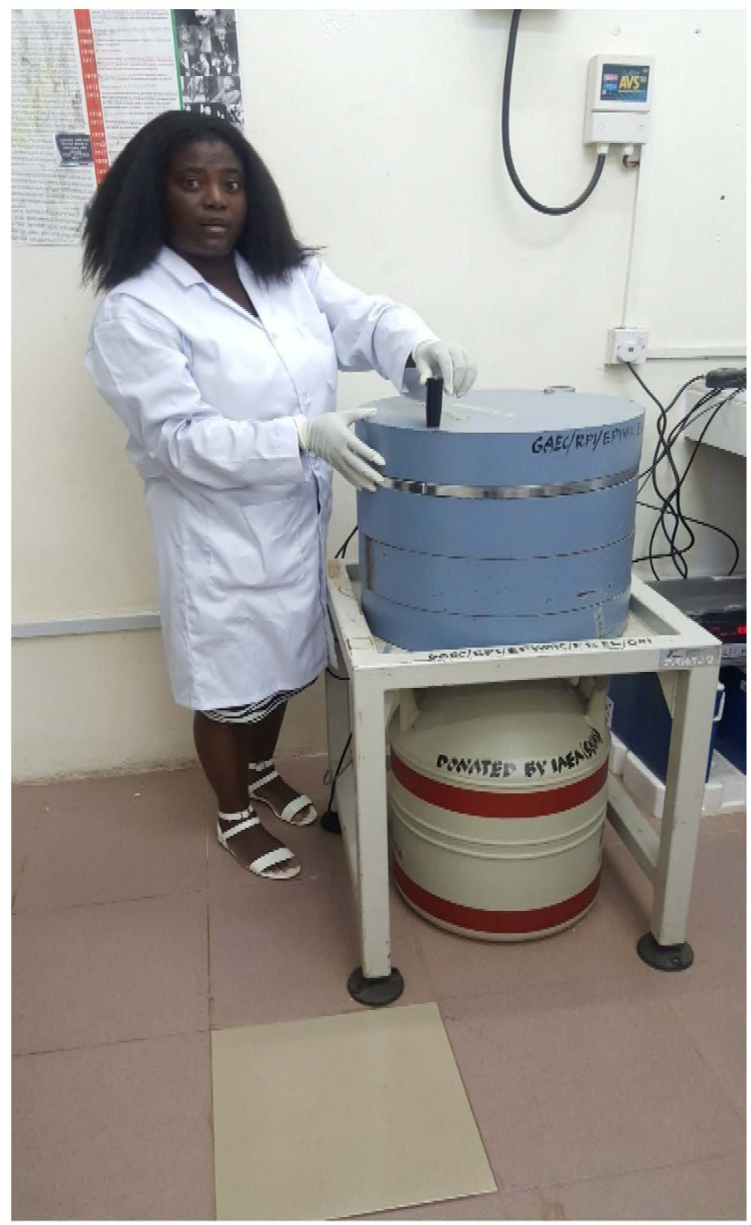

Figure 6. Shows norms measurement been carried out by a laboratory technologist using the high pure germanium detector (HPGe Detector). 


\subsection{Calibration of the Gamma Spectrometer}

A multi nuclide reference standard solution was used to calibrate the reference standard in solid water as shown in Figure 7. This standard solution was obtained from the International Atomic Energy Commission (IAEA) and it was used to determine the energy and efficiency calibration. This is conducted before commencing the analysis on the samples to ensure quantification and identification of the radionuclides as shown in Figure 7 respectively.

The multi nuclides reference standard solution is made of the following radionuclides with corresponding energies:

${ }^{203} \mathrm{Hg}(279.20 \mathrm{Ke}),{ }^{241} \mathrm{Am}(59.54 \mathrm{KeV}),{ }^{88} \mathrm{y}(898.04 \mathrm{KeV}$ and $1836.1 \mathrm{KeV}),{ }^{139} \mathrm{Ce}$ $(165.86 \mathrm{KeV}),{ }^{85} \mathrm{Sr}(514.01 \mathrm{KeV}),{ }^{60} \mathrm{Co}(1173.2 \mathrm{KeV}$ and $1332.5 \mathrm{KeV}),{ }^{113} \mathrm{Sn}$ $(391.69 \mathrm{KeV}),{ }^{109} \mathrm{Cd}(88.03 \mathrm{KeV})$ and ${ }^{57} \mathrm{Co}(122.06 \mathrm{KeV})$.

Four radionuclides were used to determine the radionuclides, these consist of: ${ }^{60} \mathrm{Co},{ }^{241} \mathrm{Am},{ }^{137} \mathrm{Cs}$ and ${ }^{57} \mathrm{Co}$ respectively. To acquire the spectra data, the standard was poured into a one litre Marilina beaker for measurement and counted for 36,000 Seconds.

\subsection{Energy Calibration}

The principal gamma rays energies in the Spectrum were calibrated both manually and the use of a computer system. A standard reference material was used to calibrate the spectrum in the channel number of the spectrometer.

The equation is express as:

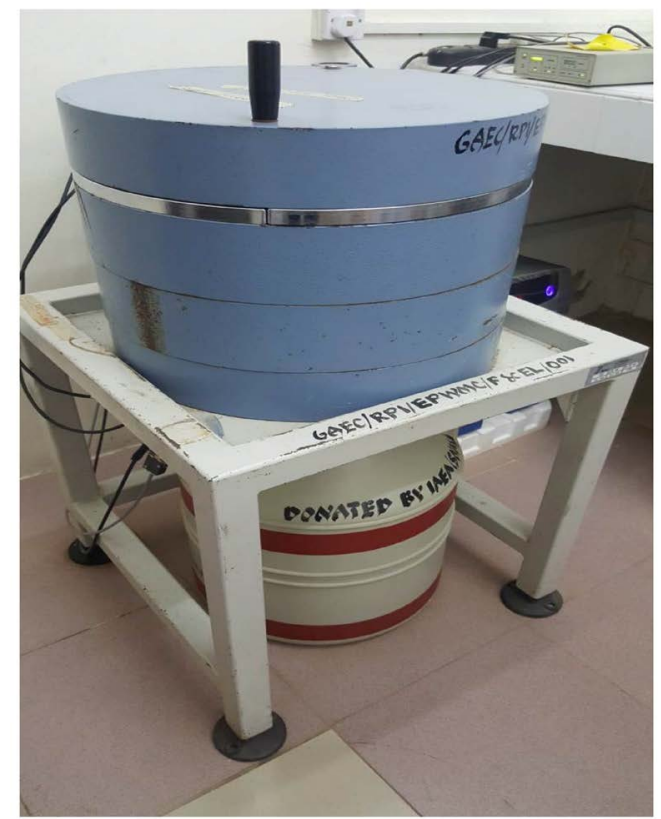

Figure 7. Shows a lead shield which is the blue equipment on top is used to cut off the background radiation from interfering with the actual concentration of the radionuclides been measured. While the equipment below which is known as Dewar contain liquid nitrogen for cooling the High Pure Germanium Detector during analysis of the borehole water samples. 


$$
\mathrm{Er}=\mathrm{a}_{\mathrm{o}}+\mathrm{a}_{1}+\mathrm{CN}
$$

where:

$\mathrm{Er}=$ the energy in $\mathrm{KeV}$.

$\mathrm{a}_{\mathrm{o}}+\mathrm{a}_{1}=$ calibration constant.

$\mathrm{CN}=$ channel number.

\subsection{Efficiency Calibration}

To determine the known activities efficiency calibration as shown in Figure 8 respectively, a standard radionuclide with define energies ranged from 60 - 2000 $\mathrm{KeV}$ was used.

A net count rate was used to determine the photo peaks for all the energies:

The equation is expressed used is given as:

$$
E(E r)=N /\left(A^{\star} P^{\star} t\right)
$$

where:

$\mathrm{Er}=$ the energy in $\mathrm{KeV}$ (Gamma emission).

$\mathrm{N}=$ the full energy peaks net count.

$\mathrm{A}=$ the activities of the source.

$\mathrm{P}=$ gamma emission probability.

$\mathrm{T}=$ the counting time.

Furthermore, another equation was used to calculate the activity concentrations in $\mathrm{Bq} / \mathrm{L}$ as shown in Figure 9 respectively. The borehole water sample this equation is given as:

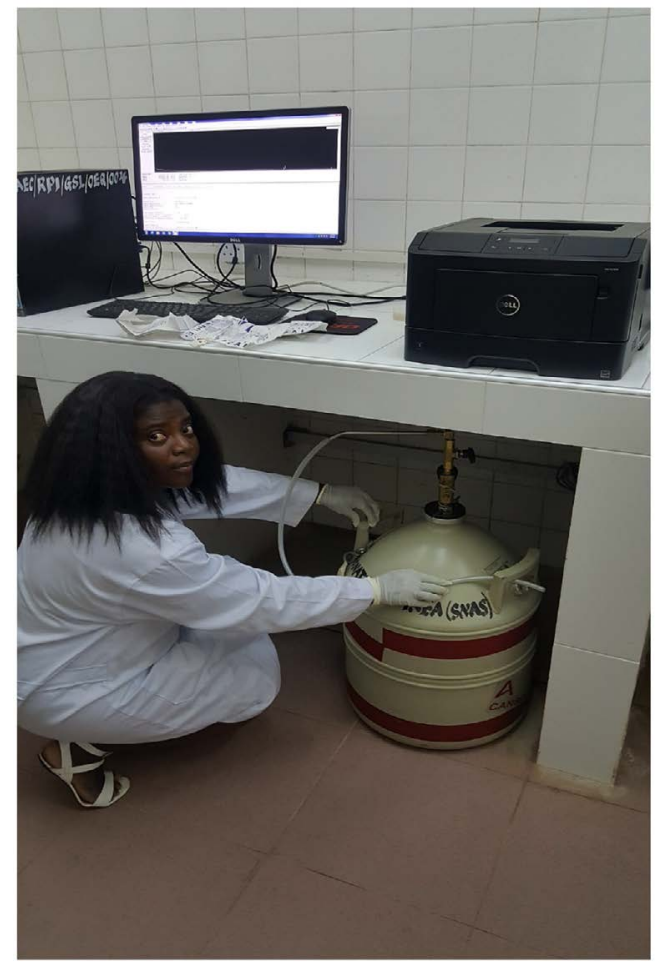

Figure 8. Laboratory technologist performing efficiency calibration of using standard radionuclides. 


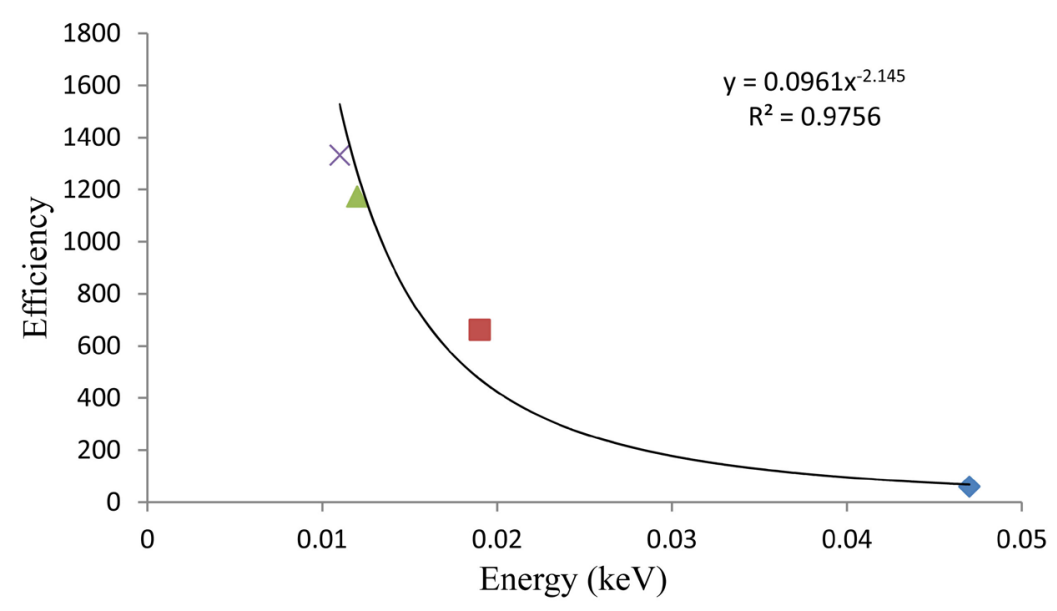

Figure 9. Shows a graph of an efficiency calibration curve.

Asp $=$ Specific activity concentration.

Nsam = background of samples.

$\mathrm{PE}=$ is the gamma yield.

$\mathrm{E}=$ the total counting efficiency.

$\mathrm{Tc}=$ sample counting time.

$\mathrm{M}=$ mass of sample $(\mathrm{Kg})$.

\subsection{Committed Effective Dose Estimation}

Each radionuclide was used to determine the committed effective dose, this was done by estimation it from the activity concentrations and using the WHO yearly water consumption rates for adults which was done by estimation it from the activity concentration and using the WHO yearly water consumption rates for adults which was given as $730 \mathrm{~L} /$ year using the expression:

$$
\text { Annual Effective dose, } \mathrm{Et}=\mathrm{e}\left(\mathrm{Aw}{ }^{\star} \mathrm{DCFw}\right){ }^{\star} \mathrm{Iw}
$$

where:

$\mathrm{Et}=$ Annual effective dose.

Aw $=$ the activity concentration.

$\mathrm{DCF}=$ the dose conversion factor in $\mathrm{mSv} / \mathrm{Bq}$.

World Health Organization recommend that for every adult, the annual consumption rate of water per year should be $730 \mathrm{~L} /$ year, which gives an estimation of $2 \mathrm{~L}$ of water per year for an adult. This implies that for every radionuclide ingested per year, in water consumption the concentration of that radionuclide in the water is multiplied by $730 \mathrm{~L}$ respectively. Normally water supply contains more than two radionuclides.

This is calculated using the following equation:

Annual dose $(\mathrm{mSv} / \mathrm{year})=$ Dose per unit intake $(\mathrm{mSv} / \mathrm{Bq}) \times$ Annual water consumption (Litre/year) $\times$ Radionuclide concentration $(\mathrm{Bq} / \mathrm{L})$.

\subsection{Data Analyses}

A Microsoft Excel as used to record the data collected. The data was expressed as 
mean \pm standard deviation differences and the mean average activity concentration of the borehole water samples. Correction test was also used to determine the activity concentration of the radionuclides and the physical parameters measured (between the $\mathrm{pH}$, the total dissolved solids, conductivity and temperature). The Ghana Standard Authority and World Health Organization recommended limits were analysed using one-sample-t-test.

\subsection{Physical Properties of Sampled Borehole Water}

The physical parameters were measured such as $\mathrm{pH}$, conductivity, total dissolve solids and temperature as shown in Table 2 respectively. From the results obtained, the results recorded that the temperature of the borehole samples ranged from $22^{\circ} \mathrm{C}$ to $29^{\circ} \mathrm{C}$ with $\mathrm{BW}_{2}$ the highest temperature and $\mathrm{BW}_{13}$ recording the lowest temperature $\left(22^{\circ} \mathrm{C}\right)$. The average temperature of the borehole was $25^{\circ} \mathrm{C}$.

\subsection{Sampling Coordinates}

The study was carried out to determine the activity concentration of fifth teen (15) different borehole water samples in different areas at the Adenta Municipality. Table 3 demonstrates the sample IDs and the coordinates of the boreholes from which the water sample was collected.

The temperature range from $22^{\circ} \mathrm{C}$ to $29^{\circ} \mathrm{C}$ respectively, as shown in Figure 10 respectively. $\mathrm{BW}_{18}$ recorded the lowest temperature and $\mathrm{BW}_{8}$ recorded the highest temperature. The average temperature was $25^{\circ} \mathrm{C}$.

Table 2. Demonstrates a result of physical parameters on the borehole water samples.

\begin{tabular}{|c|c|c|c|c|}
\hline Sample ID & $\mathrm{pH}$ & Temperature $\left({ }^{\circ} \mathrm{C}\right)$ & Conductivity $(\mu / \mathrm{cm})$ & Total dissolved solid (ppm) \\
\hline $\mathrm{BW}_{1}$ & 6.2 & 24 & 760 & 620 \\
\hline $\mathrm{BW}_{2}$ & 5.5 & 29 & 2720 & 590 \\
\hline $\mathrm{BW}_{3}$ & 4.3 & 26 & 678 & 1320 \\
\hline $\mathrm{BW}_{4}$ & 6.3 & 25 & 1780 & 720 \\
\hline $\mathrm{BW}_{5}$ & 4.6 & 22 & 699 & 349 \\
\hline $\mathrm{BW}_{6}$ & 5.5 & 26 & 754 & 1210 \\
\hline $\mathrm{BW}_{7}$ & 7.4 & 28 & 1459 & 890 \\
\hline $\mathrm{BW}_{8}$ & 5.2 & 25 & 733 & 590 \\
\hline $\mathrm{BW}_{9}$ & 5.8 & 27 & 1850 & 1290 \\
\hline $\mathrm{BW}_{10}$ & 5.1 & 27 & 792 & 990 \\
\hline $\mathrm{BW}_{11}$ & 7.1 & 25 & 771 & 420 \\
\hline $\mathrm{BW}_{12}$ & 6.9 & 23 & 891 & 570 \\
\hline $\mathrm{BW}_{13}$ & 5.9 & 27 & 832 & 450 \\
\hline $\mathrm{BW}_{14}$ & 7.1 & 24 & 1681 & 790 \\
\hline $\mathrm{BW}_{15}$ & 5.4 & 26 & 880 & 550 \\
\hline Mean Value & 5.89 & 25.6 & 1152 & 756.6 \\
\hline
\end{tabular}




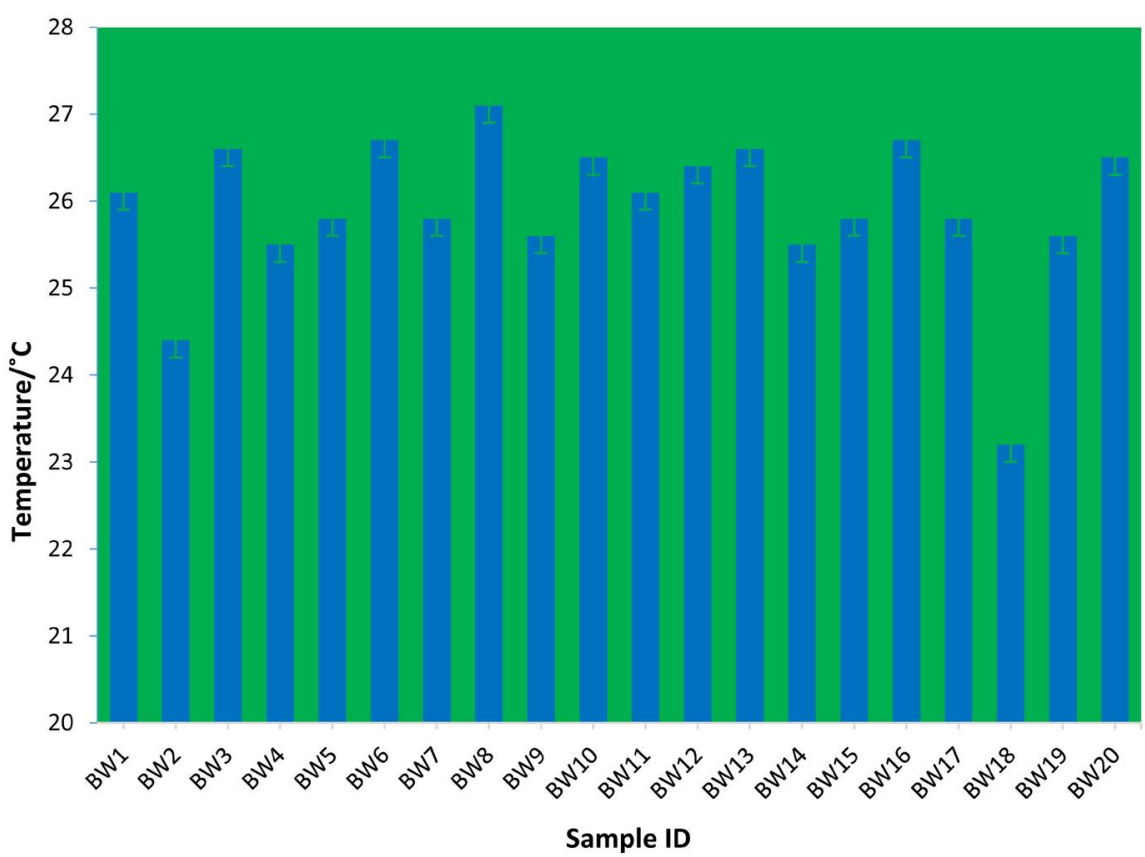

Figure 10. Shows the temperature of borehole water samples collected in the Adenta Municipality.

Table 3. Demonstrates the sample coordinates of selected boreholes in the Adenta Municipality.

\begin{tabular}{|c|c|c|}
\hline \multirow{2}{*}{ Sample ID } & \multicolumn{2}{|c|}{ Coordinates } \\
\hline & Latitude & Longitude \\
\hline $\mathrm{BW}_{1}$ & $5^{\circ} 33^{\prime} 16.20^{\prime \prime} \mathrm{N}$ & $0^{\circ} 17^{\prime} 50.12 " \mathrm{~W}$ \\
\hline $\mathrm{BW}_{2}$ & $5^{\circ} 33^{\prime} 22.30^{\prime \prime} \mathrm{N}$ & $0^{\circ} 17^{\prime} 59.24 " \mathrm{~W}$ \\
\hline $\mathrm{BW}_{3}$ & $5^{\circ} 35^{\prime} 15.24^{\prime \prime} \mathrm{N}$ & $0^{\circ} 17^{\prime} 44.16^{\prime \prime} \mathrm{W}$ \\
\hline $\mathrm{BW}_{4}$ & $5^{\circ} 33^{\prime} 17.25^{\prime \prime} \mathrm{N}$ & $0^{\circ} 17^{\prime} 50.19^{\prime \prime} \mathrm{W}$ \\
\hline $\mathrm{BW}_{5}$ & $5^{\circ} 33^{\prime} 23.26^{\prime \prime N}$ & $0^{\circ} 17^{\prime} 49.17^{\prime \prime} \mathrm{W}$ \\
\hline $\mathrm{BW}_{6}$ & $5^{\circ} 32^{\prime} 20.25^{\prime \prime} \mathrm{N}$ & $0^{\circ} 17^{\prime} 47.15^{\prime \prime} \mathrm{W}$ \\
\hline $\mathrm{BW}_{7}$ & $5^{\circ} 33^{\prime} 21.22^{\prime \prime N}$ & $0^{\circ} 17^{\prime} 49.12^{\prime \prime} \mathrm{W}$ \\
\hline $\mathrm{BW}_{8}$ & $5^{\circ} 33^{\prime} 17.23^{\prime \prime N}$ & $0^{\circ} 17^{\prime} 54.14^{\prime \prime} \mathrm{W}$ \\
\hline $\mathrm{BW}_{9}$ & $5^{\circ} 33^{\prime} 17.26^{\prime \prime N}$ & $0^{\circ} 17^{\prime} 51.16^{\prime \prime} \mathrm{W}$ \\
\hline $\mathrm{BW}_{10}$ & $5^{\circ} 32 ' 27.27^{\prime \prime} \mathrm{N}$ & $0^{\circ} 17^{\prime} 49.16^{\prime \prime} \mathrm{W}$ \\
\hline $\mathrm{BW}_{11}$ & $5^{\circ} 33^{\prime} 21.23 " \mathrm{~N}$ & $0^{\circ} 17^{\prime} 55.15^{\prime \prime} \mathrm{W}$ \\
\hline $\mathrm{BW}_{12}$ & $5^{\circ} 33^{\prime} 28.25^{\prime \prime} \mathrm{N}$ & $0^{\circ} 17^{\prime} 43.15^{\prime \prime} \mathrm{W}$ \\
\hline $\mathrm{BW}_{13}$ & $5^{\circ} 35^{\prime} 21.26^{\prime \prime N}$ & $0^{\circ} 17^{\prime} 54.19^{\prime \prime} \mathrm{W}$ \\
\hline $\mathrm{BW}_{14}$ & $5^{\circ} 33^{\prime} 18.35^{\prime \prime} \mathrm{N}$ & $0^{\circ} 17^{\prime} 59.29^{\prime \prime} \mathrm{W}$ \\
\hline $\mathrm{BW}_{15}$ & $5^{\circ} 33^{\prime} 23.30^{\prime \prime} \mathrm{N}$ & $0^{\circ} 17^{\prime} 58.24 " \mathrm{~W}$ \\
\hline
\end{tabular}

The $\mathrm{pH}$ ranged from $4-7$ as shown in Figure 11 respectively, with an average of 5.89. $\mathrm{BW}_{20}$ recorded the lowest $\mathrm{pH}$ and $\mathrm{BW}_{14}$ recorded the highest. There was no significant relationship between temperature and $\mathrm{pH}$. 


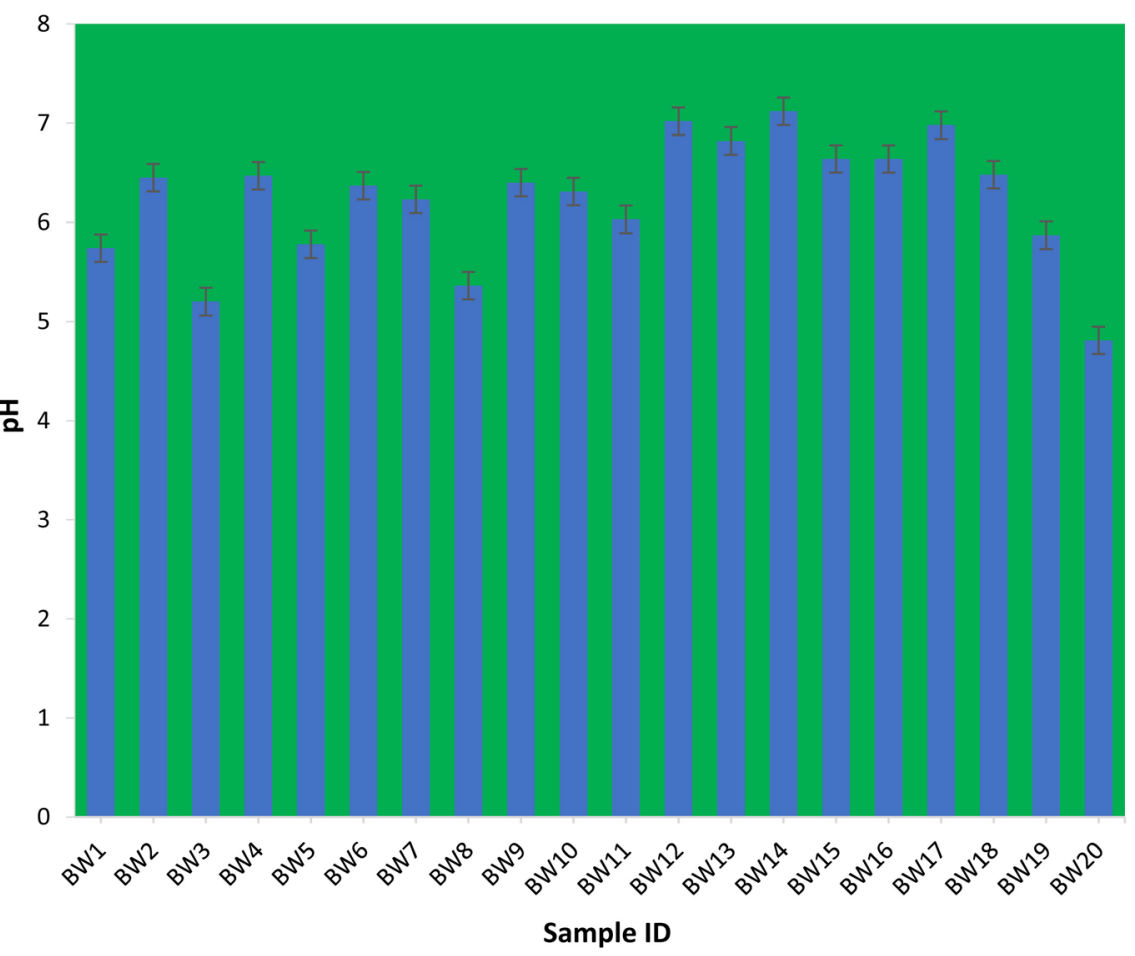

Figure 11. Shows the $\mathrm{pH}$ of borehole water samples collected in the Adenta.

The total dissolved solids ranged from $349-1320 \mathrm{ppm}, \mathrm{BW}_{17}$ recorded the highest value of $1320 \mathrm{ppm}$ and $\mathrm{BW}_{1}$ recorded the lowest ( $349 \mathrm{ppm}$ ) as shown in Figure 12 respectively. The mean average total dissolved solids was $756.6 \mathrm{ppm}$. $\mathrm{BW}_{3}, \mathrm{BW}_{6}$ and $\mathrm{BW}_{9}$ however recorded values higher that the GSA recommended limit of $1000 \mathrm{mg} / \mathrm{L}$.

$\mathrm{BW}_{7}$ which recorded the highest TDS also recorded the highest conductivity $(2720 \mu \mathrm{s} / \mathrm{cm})$ and $\mathrm{BW}_{8}$ which also recorded the lowest TDS, as shown in Figure 13 respectively, again recorded the lowest conductivity of $720 \mu \mathrm{s} / \mathrm{cm}$. The average conductivity was $1152 \mu \mathrm{s} / \mathrm{cm}$. There was a very strong positive correlation between TDS and conductivity value.

\subsection{Average Activity Concentration of ${ }^{40} \mathrm{~K}{ }^{226} \mathrm{Ra},{ }^{232} \mathrm{Th}$ and Their Annual Effective Doses of Radionuclides of the Selected Boreholes}

The WHO recommended limit for committed annual effective dose is 100 $\mu \mathrm{Sv} / \mathrm{yr}$. However, $\mathrm{BW}_{2}, \mathrm{BW}_{7}$, recorded doses higher than the recommended limit. The committed annual effective dose ranged from 5.45 to $138.41 \mu \mathrm{Sv} / \mathrm{year}$ with an average value of $33.86 \mu \mathrm{Sv} / \mathrm{yr}$. $\mathrm{BW}_{2}$ recorded the highest annual effective dose while $\mathrm{BW}_{6}$ gave the lowest effective dose. This shows that water from the borehole with identification $\mathrm{BW}_{2}$ gave the highest internal exposure to its consumers. ${ }^{40} \mathrm{~K}$ contributed the largest dose to the annual effective dose. The activity concentrations of ${ }^{40} \mathrm{~K},{ }^{226} \mathrm{Ra}$ and ${ }^{232} \mathrm{Th}$ was used to calculate the committed annual effective as a result of direct consumption of the borehole water. 


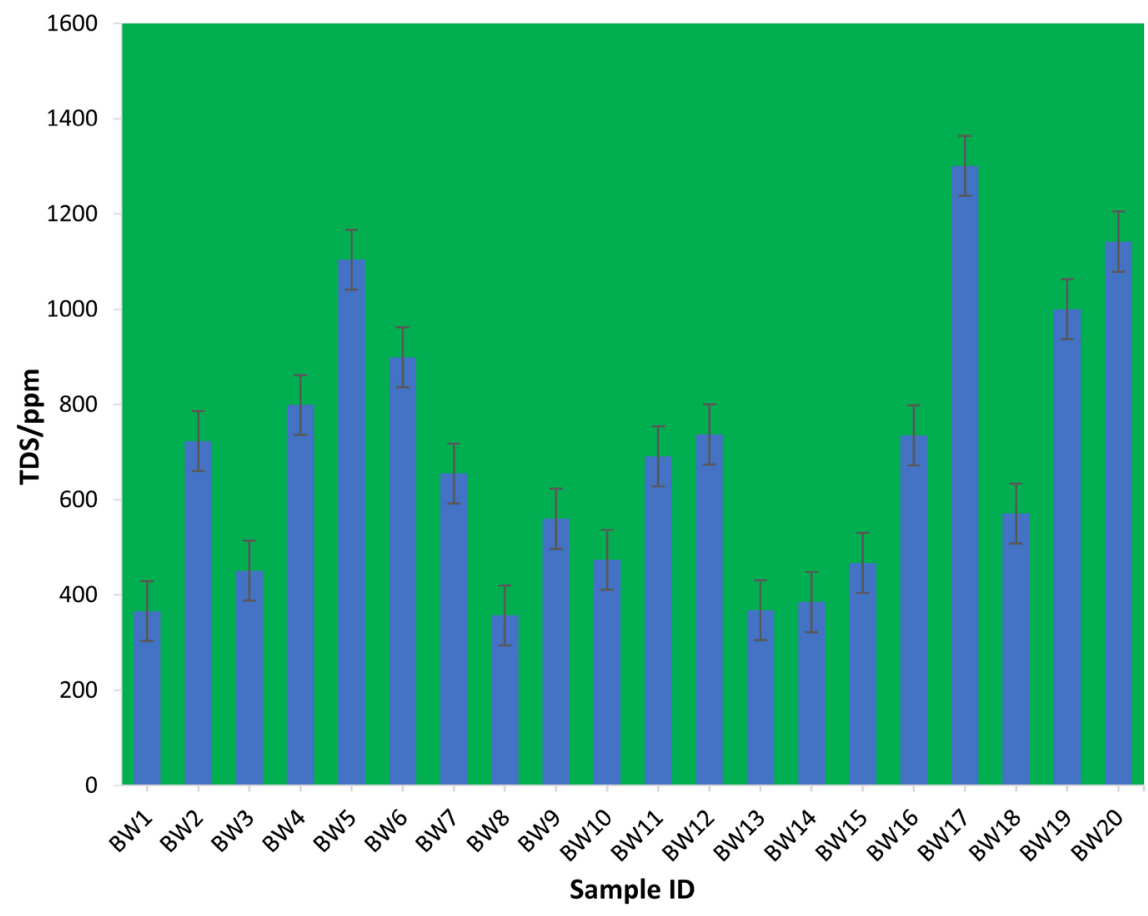

Figure 12. Shows the total dissolve solids of borehole water samples collected in Adenta.

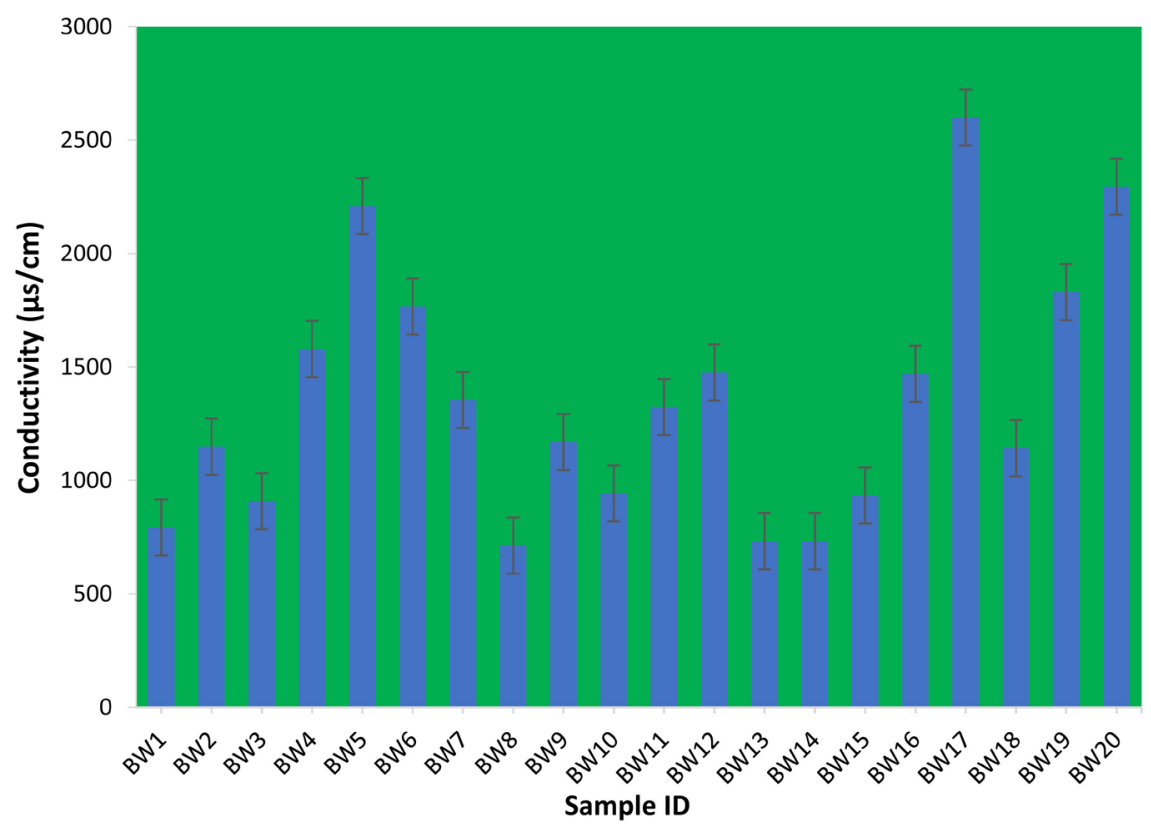

Figure 13. Shows the Conductivity of borehole water samples collected in Adenta.

The activity concentrations of ${ }^{226} \mathrm{Ra},{ }^{232} \mathrm{Th}$ and ${ }^{40} \mathrm{~K}$ in borehole water samples were measured accurately in the Adenta municipality. The mean concentration was $0.77 \pm 0.42,0.93 \pm 0.62$ and $9.77 \pm 4.55 \mathrm{~Bq} / \mathrm{L}$ for ${ }^{226} \mathrm{Ra},{ }^{232} \mathrm{Th}$ and ${ }^{40} \mathrm{~K}$ respectively. The activity concentrations of ${ }^{226} \mathrm{Ra},{ }^{232} \mathrm{Th}$ and ${ }^{40} \mathrm{~K}$ ranged from $0.13 \pm 0.08$ to $1.83 \pm 0.55 \mathrm{~Bq} / \mathrm{L}, 0.10 \pm 0.06$ to $4.29 \pm 0.27 \mathrm{~Bq} / \mathrm{L}$ and $1.24 \pm 0.16$ to $31.73 \pm$ $4.73 \mathrm{~Bq} / \mathrm{L}$ respectively. $\mathrm{BW}_{6}$ had the lowest activity concentration of ${ }^{226} \mathrm{Ra}$ while 
$\mathrm{BW}_{17}$ had the highest concentration. The highest and lowest activity concentration values of ${ }^{232} \mathrm{Th}$ were found in samples with identifications $\mathrm{BW}_{2}$ and $\mathrm{BW}_{7}$ respectively while the highest activity concentration of ${ }^{40} \mathrm{~K}$ was found in sample with $\mathrm{BW}_{19}$ and the lowest in $\mathrm{BW}_{15}$.

For ${ }^{226} \mathrm{Ra}, \mathrm{BW}_{2}$, and ${ }^{232} \mathrm{Th} \mathrm{BW}_{7}$ exceeded the WHO recommended limit of $1000 \mathrm{~Bq} / \mathrm{L}$.

\section{Discussion}

Studies have shown that the level radioactivity in water can be influenced by the physical properties of water such as conductivity and total dissolve solids. This factor was determined to help in the interpretation of the activity concentration in the borehole water. The physical parameters also help as to assess other useful information on the quality of the water.

The geological conditions of the area can also be a contributing factor in determining the total dissolve solids and the activity concentration in groundwater. The difference in the solubility's of minerals in different geological areas attribute to different concentration of total dissolved solids in.

Total dissolve solids consist of small amount of organic matter which is dissolved in water and inorganic salts mainly of sodium, chlorides, calcium, sulphates, magnesium, bicarbonates and potassium. When the total dissolve solids reach the a value of $150 \mathrm{ppm}$ the alpha counts decreases, for samples containing $241^{\mathrm{Am}}, 224^{\mathrm{Cm}}$ and $230^{\mathrm{Th}}$ the relatives efficiencies indicate a linear reduction of the sample density e relative efficiencies with increasing sample density and independent of alpha particle energy [10].

Furthermore, the Ghana Standard Authority has recommended that for drinking water the total dissolves solids should be $1000 \mathrm{mg} / \mathrm{L}$. The World Health Organization also recommends that the total dissolved solids levels greater than $1200 \mathrm{mg} / \mathrm{L}$ will be objectionable to consumers.

From this study, the temperature in the boreholes ranged from $22^{\circ} \mathrm{C}$ to $29^{\circ} \mathrm{C}$ respectively and the $\mathrm{pH}$ ranged from 6.5 to 7.9 and the total dissolved solids ranged from 960 to 5100 .

The boreholes were not expected to give accurate alpha counts due to the total dissolve solids values exceeding 150ppm. Some of the boreholes recorded values higher than the Ghana Standard Authority while the average total dissolve solids were within the acceptable limits. Additionally, the smaller total dissolved solids obtained from this study could contribute to the fact that boreholes have generally had lover total dissolves value than wells

\section{Conclusions}

The gamma-spectrometry system was used to investigate the natural radioactivity in water samples collected from boreholes in the Adenta Municipality in the Greater Accra Region of Ghana. The activity concentrations of ${ }^{40} \mathrm{~K},{ }^{226} \mathrm{Ra}$ and ${ }^{232} \mathrm{Th}$ ranged from $0.27 \pm 0.05$ to $1.83 \pm 0.55 \mathrm{~Bq} / \mathrm{L}, 0.11 \pm 0.06$ to $4.29 \pm 0.27 \mathrm{~Bq} / \mathrm{L}$ 
and $1.24 \pm 0.16$ to $28.75 \pm 4.82 \mathrm{~Bq} / \mathrm{L}$ respectively. The mean concentration values were $0.77 \pm 0.42,0.93 \pm 0.62$ and $9.77 \pm 4.55 \mathrm{~Bq} / \mathrm{L}$ for ${ }^{40} \mathrm{~K},{ }^{226} \mathrm{Ra}$, and ${ }^{232} \mathrm{Th}$ respectively.

From the estimation obtained, it was found out that the committed annual effective dose to an adult individual due to intake of natural radionuclides in the borehole water was far below the World Health Organization level. The estimation shows $39.26 \pm 80 \mu \mathrm{Sv} / \mathrm{yr}$ which is far below the WHO recommended limit of $100 \mu \mathrm{Sv} / \mathrm{yr}$. Moreover, some boreholes recorded values above the recommended limit. It was therefore concluded that not all the water in boreholes in the Adenta Municipality are safe for drinking, this implies that some inhabitants in the Adenta municipality may be exposed to some degree of significant radiological health hazard due to the intake of drinking water from boreholes in the municipality as shown in Table 4 respectively.

\section{Committed Annual Effective Dose}

The annual effective doses due to intake of radionuclides were calculated using the World Health Organization consumption rates of $2 \mathrm{~L}$ of water per day that was used to calculate the annual effective dose due to intake of radionuclides which correspond to $730 \mathrm{~L} /$ year [11]. The calculated mean annual effective dose for

Table 4. Demonstrates the activity concentration and annual effective dose for ${ }^{40} \mathrm{~K},{ }^{266} \mathrm{Ra}$ and ${ }^{232} \mathrm{Th}$.

\begin{tabular}{|c|c|c|c|c|}
\hline \multirow{2}{*}{ Sample } & \multicolumn{3}{|c|}{ Activity concentration, $\mathrm{Bq} / \mathrm{L}$} & \multirow{2}{*}{$\begin{array}{c}\text { Annual effective } \\
\text { dose, } \mu \mathrm{Sv} / \mathrm{yr}\end{array}$} \\
\hline & ${ }^{40} \mathrm{~K}$ & ${ }^{266} \mathrm{Ra}$ & ${ }^{232} \mathrm{Th}$ & \\
\hline $\mathrm{BW}_{1}$ & $8.10 \pm 0.06$ & $0.42 \pm 0.17$ & $0.31 \pm 0.05$ & 6.58 \\
\hline $\mathrm{BW}_{2}$ & $24.15 \pm 3.23$ & $1.34 \pm 0.14$ & $0.41 \pm 0.06$ & 138.41 \\
\hline $\mathrm{BW}_{3}$ & $1.40 \pm 0.22$ & $0.38 \pm 0.32$ & $0.65 \pm 0.15$ & 9.33 \\
\hline $\mathrm{BW}_{4}$ & $4.20 \pm 0.23$ & $0.62 \pm 0.16$ & $2.35 \pm 0.45$ & 10.58 \\
\hline $\mathrm{BW}_{5}$ & $3.15 \pm 0.22$ & $0.81 \pm 0.26$ & $1.62 \pm 0.10$ & 15.10 \\
\hline $\mathrm{BW}_{6}$ & $3.10 \pm 0.41$ & $0.29 \pm 0.09$ & $0.36 \pm 0.12$ & 5.45 \\
\hline $\mathrm{BW}_{7}$ & $30.75 \pm 4.62$ & $0.86 \pm 0.17$ & $0.15 \pm 0.08$ & 131.21 \\
\hline $\mathrm{BW}_{8}$ & $5.68 \pm 4.83$ & $0.59 \pm 0.06$ & $0.13 \pm 0.07$ & 21.65 \\
\hline $\mathrm{BW}_{9}$ & $13.43 \pm 3.76$ & $0.85 \pm 0.29$ & $0.18 \pm 0.05$ & 66.84 \\
\hline $\mathrm{BW}_{10}$ & $3.47 \pm 0.36$ & $0.36 \pm 0.02$ & $1.26 \pm 0.16$ & 7.20 \\
\hline $\mathrm{BW}_{11}$ & $2.53 \pm 0.15$ & $0.30 \pm 0.08$ & $0.60 \pm 0.07$ & 8.24 \\
\hline $\mathrm{BW}_{12}$ & $7.67 \pm 0.25$ & $2.03 \pm 0.17$ & $0.38 \pm 0.08$ & 28.76 \\
\hline $\mathrm{BW}_{13}$ & $8.39 \pm 0.68$ & $1.66 \pm 0.15$ & $1.19 \pm 0.12$ & 40.35 \\
\hline $\mathrm{BW}_{14}$ & $12.0 \pm 0.09$ & $1.33 \pm 0.16$ & $0.36 \pm 0.09$ & 8.50 \\
\hline $\mathrm{BW}_{15}$ & $3.44 \pm 0.12$ & $0.45 \pm 0.08$ & $0.45 \pm 0.06$ & 9.75 \\
\hline Mean & $8.76 \pm 1.28$ & $0.82 \pm 0.15$ & $0.69 \pm 0.11$ & 33.86 \\
\hline WHO Guideline level & 1.00 & 1.00 & N/A & 100.00 \\
\hline
\end{tabular}


this research work is $33.86 \mu \mathrm{Sv} / \mathrm{yr}$ which is far below the recommended limit given by World Health Organization, meanwhile some of the borehole recorded higher values, which is not radiologically safe for drinking. Apart from radon and tritium radionuclides, the World Health Organization Guildlines state that the total annual effective dose should not exceed $100 \mu \mathrm{Sv} / \mathrm{yr}$.

\section{Acknowledgements}

The authors would like to acknowledge the Ghana Atomic Energy Commission, especially the Radiation Protection Institute for allowing them to use their laboratories, facilities and staff during the preparation of this research work. Our gratitude also goes to the staff and support of the Graduate School for their proper proof reading on this write-up.

\section{Conflicts of Interest}

The authors duly agreed that there is no conflict of interest as far as the publication of this research work is concerned.

\section{References}

[1] Ahmed, N.K. (2004) Natural Radioactivity of Ground and Drinking Water in Some Areas of Upper Egypt. Turkish Journal of Engineering and Environmental Sciences, 28, 345-354.

[2] Al-Amir, S.M., Al-Hamarneh, et al. (2012) Natural Radioactivity in Tap Water and Associated Age-Dependent Dose and Lifetime Risk Assessment in Amman, Jordan. Applied Radiation and Isotopes, 70, 692-698. https://doi.org/10.1016/j.apradiso.2011.12.002

[3] Bonotto, D.M., Bueno, T.O., et al. (2008) The Natural Radioactivity in Guarani Aquifer Groundwater, Brazil. Applied Radiation and Isotopes, 66, 1507-1522. https://doi.org/10.1016/j.apradiso.2008.03.008

[4] Chau, N., Jodlowski, M., et al. (2011) Natural Radioactivity in Groundwater-A Review. Isotopes in Environmental and Health Studies, 47, 415-437. https://doi.org/10.1080/10256016.2011.628123

[5] Darko, E.O., Awudu, S., et al. (2011) Preliminary Study of Natural Radioactivity in the Bosumtwi Lake Basin. Environmental and Earth Sciences, 41, 5761-5765.

[6] Darko, E.O., Adukpo, O., Fletcher, K., et al. (2010) Preliminary Studies on 222Rn Concentration in Ground Water from Selected Areas of the Accra Metropolis in Ghana. Journal of Radioanalytical and Nuclear Chemistry, 283, 507-512. https://doi.org/10.1007/s10967-009-0378-y

[7] Faanu, A., Kpeglo, D., et al. (2013) Natural and Artificial Radioactivity Distribution in Soil, Rock and Water of the Central Ashanti Gold Mine, Ghana. Environmental Earth Sciences, 70, 1593-1604. https://doi.org/10.1007/s12665-013-2244-Z

[8] Jia, G., Torri, G., et al. (2009) Concentrations of 238U, 234U, 235U, 232Th, 230Th, 228Th, 226Ra, 228Ra, 224Ra, 210Po, 210Pb and 212Pb in Drinking Water in Italy: Reconciling Safety Standards Based on Measurements of Gross Alpha and Beta. Journal of Environmental Radioactivity, 100, 941-949. https://doi.org/10.1016/j.jenvrad.2009.07.002

[9] Kozłowska, B., et al. (2007) Uranium, Radium and ${ }^{40} \mathrm{~K}$ Isotopes in Bottled Mineral 
Waters from Outer Carpathians, Poland. Radiation Measurements, 42, 1380-1386. https://doi.org/10.1016/j.radmeas.2007.03.004

[10] Vesterbacka, P. (2007) Natural Radioactivity in Drinking Water in Finland. Boreal Environment Research, 12, 11-16. https://doi.org/10.1097/00004032-198007000-00009

[11] WHO (2008) Guidelines for Drinking-Water Quality (Vol. 1). Geneva. 